\title{
Elimination of the Fast Transient in Superior Cervical Ganglion Neurons with Expression of KV4.2W362F: Molecular Dissection of $I_{A}$
}

\author{
Sacha A. Malin and Jeanne M. Nerbonne \\ Department of Molecular Biology and Pharmacology, Washington University School of Medicine, St. Louis, Missouri 63110
}

\begin{abstract}
Electrophysiological and molecular studies have revealed considerable heterogeneity in voltage-gated $\mathrm{K}^{+}$currents and in the subunits that underlie these channels in mammalian neurons. At present, however, the relationship between native $\mathrm{K}^{+}$currents and cloned subunits is poorly understood. In the experiments here, a molecular genetic approach was exploited to define the molecular correlate of the fast transient outward $\mathrm{K}^{+}$current, $I_{\mathrm{Af}}$, in sympathetic neurons and to explore the functional role of $I_{\text {Af }}$ in shaping action potential waveforms and controlling repetitive firing patterns. Using the biolistic gene gun, cDNAs encoding a dominant negative mutant Kv4.2 $\alpha$-subunit (Kv4.2W362F) and enhanced green fluorescent protein (EGFP) were introduced into rat sympathetic neurons in vitro. Whole-cell voltage-clamp recordings obtained from EGFP-positive cells revealed that $I_{\text {Af }}$ is selectively eliminated in cells expressing Kv4.2W362F, demonstrating that $\mathrm{Kv} 4 \alpha$-subunits underlie $I_{\text {Af }}$ in sympathetic neurons.
\end{abstract}

Voltage-gated potassium $\left(\mathrm{K}^{+}\right)$currents are key regulators of excitability in mammalian neurons, and in most cell types, two broad classes of voltage-gated $\mathrm{K}^{+}$currents have been distinguished: (1) rapidly activating and inactivating currents, $I_{\mathrm{A}}$, and (2) delayed rectifier $\mathrm{K}^{+}$currents, $I_{\mathrm{K}}$ (Rudy, 1988; Storm, 1990). These are broad classifications, however, and in most mammalian neurons, multiple $\mathrm{K}^{+}$current components with distinct time- and voltagedependent properties have been identified. This diversity has physiological significance because the various $\mathrm{K}^{+}$currents contribute to determining the waveforms of individual action potentials and repetitive firing patterns (Pongs, 1999). Molecular cloning of $\mathrm{K}^{+}$ channel pore-forming $\alpha$ - and $\beta$-subunits has revealed considerably more heterogeneity (Coetzee et al., 1999) than was expected based on the physiology, and the relationships between these subunits and functional neuronal voltage-gated $\mathrm{K}^{+}$channels are not well understood.

At present, there is considerable interest in determining the molecular correlates of functional voltage-gated $\mathrm{K}^{+}$channels in mammalian neurons and in defining the roles of these channels in shaping action potential waveforms, repetitive firing patterns, and responses to synaptic inputs (Coetzee et al., 1999). In the experiments here, a molecular genetic approach has been exploited to address these issues in neurons isolated from the superior cervical ganglion (SCG) of the rat. Previous studies have documented the expression of (at least) three voltage-gated outward $\mathrm{K}^{+}$currents in rat SCG neurons: a fast transient 4-aminopyridine (4-AP)-sensitive current $\left(I_{\mathrm{A}}\right)$, a slowly activating and inactivating tetraethylammo-

\footnotetext{
Received March 14, 2000; revised April 24, 2000; accepted April 25, 2000.

Correspondence should be addressed to Dr. J. M. Nerbonne, Washington University Medical School, 660 S. Euclid, Box 8130, St. Louis, MO 63110. E-mail: jnerbonn@pcg.wustl.edu.

This work was supported by the National Science Foundation (predoctoral fellowship to S.A.M.) and National Institutes of Health (NS-30676). We thank Dr. Dianne Barry for the wild-type Kv4.2 and mutant Kv4.2W362F constructs and Pat Lampe for providing SCG cultures for some of the preliminary experiments. The technical assistance provided by Rebecca Hood and Amy Coleman in the preparation and maintenance of the glial monolayer cultures and by Andrew Benedict with the confocal microscopy is gratefully acknowledged.

Copyright (C) 2000 Society for Neuroscience $0270-6474 / 00 / 205191-09 \$ 15.00 / 0$
}

In addition, $I_{\text {Af }}$ density is increased significantly in cells overexpressing wild-type Kv4.2. In cells expressing Kv4.2W362F, input resistances are increased and (current) thresholds for action potential generation are decreased, demonstrating that $I_{\text {Af }}$ plays a pivotal role in regulating excitability. Expression of Kv4.2W362F and elimination of $I_{\text {Af }}$ also alters the distribution of repetitive firing patterns observed in response to a prolonged injection of depolarizing current. The wild-type superior cervical ganglion is composed of phasic, adapting, and tonic firing neurons. Elimination of $I_{\text {Af }}$ increases the percentage of adapting cells by shifting phasic cells to the adapting firing pattern, and increased $I_{\text {Af }}$ density reduces the number of adapting cells.

Key words: $K^{+}$channels; I $I_{A}$ Kv4 $\alpha$-subunits; Kv4.2W362F; transgenics; gene gun; neuronal excitability; repetitive firing patterns nium (TEA)-sensitive delayed rectifier current $\left(I_{K}\right)$, and, a steadystate component (Freshi, 1983; Galvan and Sedlmeir, 1984; Belluzzi et al., 1985a,b). A number of voltage-gated $\mathrm{K}^{+}$channel $(\mathrm{Kv})$ pore-forming $\alpha$-subunits, including Kv1.1, 1.2, 1.3, 1.4, 2.1, 2.2, 4.1, 4.2 , and 4.3 , that likely contribute to these currents have been shown to be expressed in rat SCG (Dixon and McKinnon, 1996; Pankevych et al., 1999). Of these subunits, only Kv1.4 and Kv4.1, $\mathrm{Kv} 4.2$, and Kv4.3 produce rapidly activating and inactivating 4-APsensitive currents (Coetzee et al., 1999) that resemble the transient outward current $I_{\mathrm{A}}$ in SCG neurons.

Previous studies have demonstrated that $\alpha$-subunits of the $\mathrm{Kv} 4$ subfamily underlie the fast component of the transient current $I_{\text {to,f }}$ in cardiac cells (Fiset et al., 1997; Johns et al., 1997; Barry et al., 1998; Xu et al., 1999a), and several lines of evidence suggest that $\mathrm{Kv} 4 \alpha$-subunits play a role in the generation of $I_{\mathrm{A}}$ in central neurons (Serodio et al., 1994; Baro et al., 1997; Johns et al., 1997; Martina et al., 1998; Song et al., 1998; Tkatch et al., 2000). The experiments here were undertaken, therefore, to test directly the hypothesis that Kv4 $\alpha$-subunits contribute to $I_{\mathrm{A}}$ in sympathetic neurons by examining the effects of expression of a mutant Kv4 $\alpha$-subunit, $\mathrm{Kv} 4.2 \mathrm{~W} 362 \mathrm{~F}$, that functions as a dominant negative (Barry et al., 1998). The results reveal that the fast transient current, $I_{\mathrm{Af}}$, is eliminated in SCG cells expressing Kv4.2W362F. Experiments focused on exploring the functional consequences of elimination of $I_{\text {Af }}$ on the waveforms of action potentials and the repetitive firing properties of SCG cells are also presented.

\section{MATERIALS AND METHODS}

Culture of SCG neurons. Sympathetic neurons were isolated from the SCG of embryonic day 21 (E21) to postnatal day 1 (P1) Long-Evans rat pups using a procedure similar to that described by Chang et al. (1990). Briefly, after anesthesia with 5\% halothane, animals were decapitated, and the SCG was removed. Ganglia were successively incubated for 30 min periods in collagenase and trypsin at room temperature; isolated SCG neurons were obtained by trituration and subsequent centrifugation. Dissociated SCG cells were resuspended in growth medium [Earle's Minimum Essential Medium (EMEM) with $10 \%$ fetal calf serum (FCS), $0.14 \mathrm{~mm}$ L-glutamine, $100 \mathrm{U} / \mathrm{ml}$ penicillin/streptomycin and $0.05 \mathrm{mM} \mathrm{NGF]} \mathrm{and}$ plated at a density of $2.5 \times 10^{4} / \mathrm{cm}^{2}$ on glial monolayers [prepared as in Raff et al. (1979)]. Cells were maintained in a $95 \% \quad \mathrm{O}_{2} / 5 \% \mathrm{CO}_{2} \quad 37^{\circ} \mathrm{C}$ 
incubator, and the medium was exchanged with fresh growth medium approximately every $48 \mathrm{hr}$.

Immunohistochemistry. The affinity-purified rabbit polyclonal anti-Kv4 pan antibody used in this study was raised against residues $484-502$ in the $\mathrm{C}$ terminus of $\mathrm{Kv} 4.2$, and it has been shown to reliably detect Kv4.2 and Kv4.3 (Barry et al., 1995). The corresponding sequence in Kv4.1 is similar ( $\sim 80 \%$ identical to the Kv4.2 sequence), and it is assumed that this antibody will also recognize Kv4.1. Polyclonal antibodies generated against unique sequences in Kv4.2 and Kv4.3 were also used. The Kv4.3-specific antibody was targeted against residues $450-467$ in the C-terminal region of Kv4.3 and has been shown previously to detect Kv4.3 with no detectable cross-reactivity with Kv4.2 (Brahmajothi et al., 1999). The anti-Kv4.2 antibody was generated against amino acid residues $29-38$ in the $\mathrm{N}$ terminus of Kv4.2. As in previous studies (Barry et al., 1995; Brahmajothi et al., 1999; Pond et al., 2000), antibody specificity and cross-reactivity were assessed by immunohistochemical and Western blot analysis of cells transiently expressing Kv4.2, Kv4.3, or another Kv $\alpha$-subunit. The anti-Kv4.2 antibody only detects Kv4.2; no cross-reactivity is observed (R. Hood, B. K. Scheve, and J. M. Nerbonne, unpublished observations). A mouse monoclonal anti-FLAG M2 antibody (Kodak) was used (at a 1:500 dilution) to detect the Kv4.2W362F-FLAG protein in transfected SCG neurons. For immunohistochemistry, cells were fixed in $4 \%$ paraformaldehyde for $30 \mathrm{~min}$, incubated in blocking buffer (PBS containing 5\% normal goat serum, $0.02 \%$ Triton $\mathrm{X}-100$, and $0.1 \% \mathrm{NaNH}_{3}$ ) for $1 \mathrm{hr}$ and labeled with a primary antibody (1:100 dilution) at $4^{\mathrm{O}}$ overnight. After washing, cultures were incubated with a Cy3-labeled goat anti-rabbit (or rabbit anti-mouse) IgG secondary antibody (Chemicon, Temecula, CA). After washing, labeled cells were visualized with laser illumination using a Zeiss inverted confocal microscope, and images were captured in $1 \mu \mathrm{m}$ sections.

Transfection of isolated SCG neurons with the gene gun. In preliminary experiments, $1.6 \mu \mathrm{m}$ gold beads were coated with pCMV-EGFP (Clonetech), which encodes enhanced green fluorescent protein (EGFP), and propelled (450 psi; $2 \mathrm{~mm}$ carrier distance) into SCG neurons at $4 \mathrm{~d}$ in vitro using the gene gun (Bio-Rad), a biolistic projectile system. After transfections, the cultures appeared healthy, and expression of EGFP was readily detected $24 \mathrm{hr}$ later (see Results). In experiments aimed at examining the effects of Kv4.2W362F or Kv4.2 expression in SCG neurons, the gold particles were coated with either pBK-CMV-Kv4.2 and pCMV-EGFP or pBK-CM V-Kv4.2W362F-FLAG and pCMV-EGFP in a 4:1 ratio (total of $10 \mu \mathrm{g}$ of DNA). Because EGFP expression was used to identify transfected neurons for subsequent electrophysiological characterization, immunohistochemical experiments were performed to determine whether EGFPexpressing cells also expressed the Kv4.2W362F-FLAG construct (see Results).

Electrophysiological recording. Whole-cell recordings were obtained from isolated SCG neurons at room temperature $\left(22-25^{\circ} \mathrm{C}\right)$. Data were collected using an Axopatch-1B patch-clamp amplifier; experimental parameters were controlled with a P5-120 Gateway2000 computer through a TL-1 DMA Interface using the PClamp7 software package (Axon Instruments). Electrodes were fabricated from soda-lime glass (Chase 2502) with a two-stage puller, and the shanks were coated with a silicone elastomer (Sylgard, Dow Corning, Corning, NY). Pipette resistances were 1.5-3 M $\Omega$ after fire-polishing. For voltage-clamp recordings, the bath solution routinely contained (in $\mathrm{mM}$ ): $140 \mathrm{NaCl}, 4 \mathrm{KCl}, 2 \mathrm{CaCl}_{2}, 2 \mathrm{MgCl}_{2}, 10 \mathrm{HEPES}$, 5 glucose, 0.001 TTX, and $0.1 \mathrm{CdCl}_{2}(\mathrm{pH} 7.5,300 \mathrm{mOsm})$. Recordings were also obtained from SCG neurons in the current-clamp mode, and the TTX and $\mathrm{CdCl}_{2}$ were omitted from the bath for these studies. The pipette solution for both current and voltage-clamp recordings contained (in $\mathrm{mM}$ ): $135 \mathrm{KCl}, 10 \mathrm{HEPES}, 5$ glucose, $3 \mathrm{MgATP}, 0.5 \mathrm{NaATP}, 2 \mathrm{EGTA}, 1.1 \mathrm{CaCl}_{2}$ $(\mathrm{pH} 7.5,300 \mathrm{mOsm})$. Series resistances, estimated from the decays of the uncompensated capacitative transients, were 2-5 M $\Omega$ and were compensated electronically by $\sim 80-90 \%$. Because current amplitudes were $<10$ $\mathrm{nA}$, the voltage errors resulting from the uncompensated series resistance were always $<10 \mathrm{mV}$ and were not corrected. Voltage-gated $\mathrm{K}^{+}$currents were evoked during $125 \mathrm{msec}$ or $6 \mathrm{sec}$ depolarizing voltage steps to test potentials between $-40 \mathrm{mV}$ and $+50 \mathrm{mV}$ from a holding potential of -90 $\mathrm{mV}$. Single action potentials and action potential trains were recorded in response to brief (1.5 msec) 200-400 pA and prolonged (500 msec) 20-200 $\mathrm{pA}$ depolarizing current injections.

Data analysis. Data were compiled and analyzed using pCLAMP7 (Axon) and Excel (Microsoft) software and are presented as means \pm SEM. To ensure adequate spatial control of the membrane voltage, the decay phase of the capacitative transients were analyzed, and only cells in which $>90 \%$ of the amplitude of the capacitative transient decayed with a single exponential time course were included in this study. Only data obtained from cells with an input resistance $>100 \mathrm{M} \Omega$ were analyzed and included here. The mean $( \pm \mathrm{SEM})$ input resistance and capacitance of EGFP-expressing SCG neurons were $0.34 \pm 0.03 \mathrm{G} \Omega$ and $32 \pm 2 \mathrm{pF}(n=$ 43 ), respectively. Leak currents were $<100 \mathrm{pA}$ (at $-70 \mathrm{mV}$ ) and were not subtracted. To determine the amplitudes and the decay time constants of the individual components of the total depolarization-activated outward $\mathrm{K}^{+}$currents in SCG neurons, the inactivation phases of the currents recorded during prolonged $(6 \mathrm{sec})$ depolarizations were analyzed using the equation $y=A_{1} \mathrm{e}^{-\mathrm{t} / \tau 1}+A_{2} \mathrm{e}^{-\mathrm{t} / \tau 2}+A_{3} \mathrm{e}^{-\mathrm{t} / \tau 3}+C$, where $A_{1}, A_{2}$, and $A_{3}$ (measured in $\mathrm{pA} / \mathrm{pF}$ ) are the amplitudes of the inactivating current components $\left(I_{\mathrm{Af}}, I_{\mathrm{As}}\right.$, and $\left.I_{\mathrm{K}}\right)$ that decay with $\tau_{1}, \tau_{2}$, and $\tau_{3}$ (measured in milliseconds), respectively, and $C$ is the steady-state current (measured in

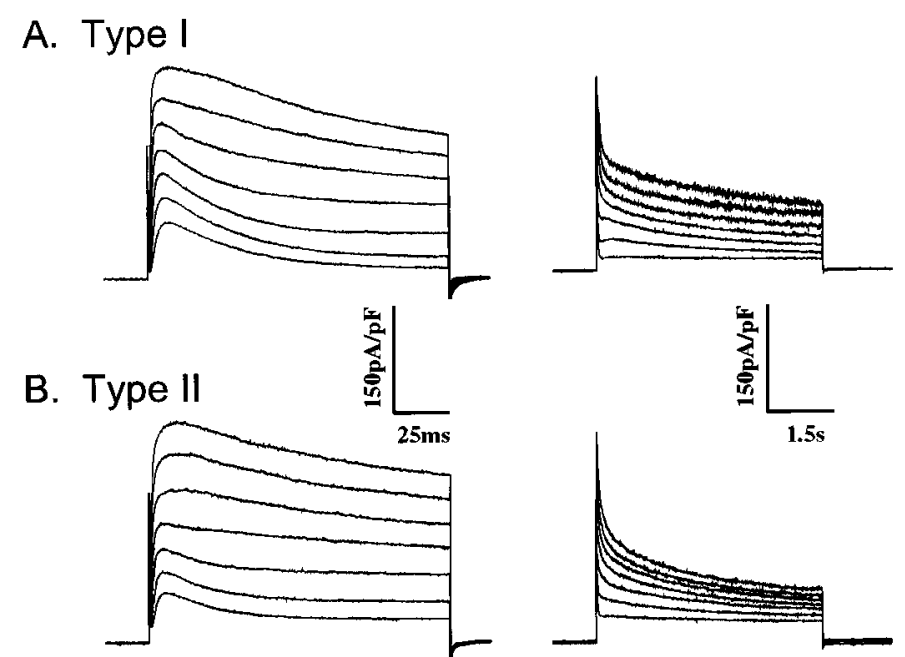

\section{Type III}
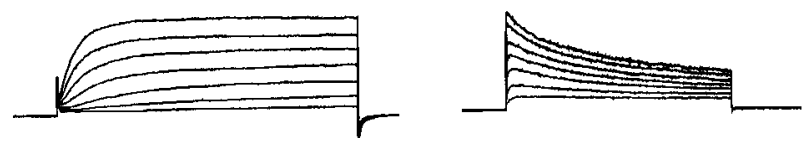

Figure 1. Voltage-gated outward $\mathrm{K}^{+}$current waveforms in SCG neurons. Whole-cell outward $\mathrm{K}^{+}$currents were recorded from isolated SCG neurons in response to $125 \mathrm{msec}$ (left panels) and $6 \mathrm{sec}$ (right panels) depolarizing voltage steps from a holding potential of $-90 \mathrm{mV}$. Experiments were conducted as described in Materials and Methods with $1 \mu \mathrm{M}$ TTX and 100 $\mu \mathrm{M} \mathrm{CdCl}$ in the bath solution to block voltage-gated inward $\mathrm{Na}^{+}$and $\mathrm{Ca}^{2+}$ currents, respectively. The left and right panels in $A-C$ were recorded from the same cell. There are distinct and stereotyped differences in the waveforms of the currents in Type I, II, and III cells (see Results and Table $1)$. There is a prominent rapid component of current decay in Type $\mathrm{I}(A)$ and II $(B)$ cells that is not evident in Type III $(C)$ cells; current activation is also slower in Type III $(C)$ cells (see Results).

$\mathrm{pA} / \mathrm{pF}$ ) remaining at the end of the $6 \mathrm{sec}$ depolarization (see Results). Fits were obtained using CLAMPFIT6, and best fits were determined by eye (in all cases, $\sigma<30 \mathrm{pA}$ ). All current-clamp recordings were obtained from cells with overshooting action potentials and stable resting membrane potentials negative to $-50 \mathrm{mV}$. Action potential durations were measured at $50 \%\left(\mathrm{APD}_{50}\right)$ and $90 \%\left(\mathrm{APD}_{90}\right)$ repolarization. Statistical significance was examined with the Student's $t$ test, and where appropriate, $p$ values are presented in the text.

\section{RESULTS}

\section{Multiple components of the outward $\mathrm{K}^{+}$currents in SCG neurons}

In the experiments here, neurons were isolated from the SCG of E21 or P1 rats, plated on glial monolayers, and maintained in vitro. Whole-cell voltage-gated $\mathrm{K}^{+}$currents were recorded in the presence of $1 \mu \mathrm{M}$ TTX and $0.1 \mathrm{~mm} \mathrm{CdCl} \mathrm{Cl}_{2}$ to block voltage-gated $\mathrm{Na}^{+}$ and $\mathrm{Ca}^{2+}$ currents, respectively. Representative outward currents recorded from (three) isolated SCG neurons in response to brief $(125 \mathrm{msec})$ and prolonged $(6 \mathrm{sec})$ membrane depolarizations to varying test potentials from a holding potential of $-90 \mathrm{mV}$ are presented in Figure 1. The rates of rise and the amplitudes of the currents increase with increasing membrane depolarization; the largest and most rapidly activating current in each panel of Figure 1 was evoked at $+50 \mathrm{mV}$. No voltage-gated $\mathrm{K}^{+}$currents were recorded when the $\mathrm{K}^{+}$in the recording pipettes was replaced with $\mathrm{Cs}^{+}(n=9)$. The currents recorded (Fig. 1) and analyzed here, therefore, are assumed to reflect only the currents through $\mathrm{Ca}^{2+}$. independent voltage-gated $\mathrm{K}^{+}$channels.

As is clearly evident in Figure 1, the amplitudes and the waveforms of the outward $\mathrm{K}^{+}$currents vary markedly among SCG neurons. Nevertheless, outward $\mathrm{K}^{+}$current waveforms in SCG cells are stereotyped, and the records shown in Figure $1 A-C$ are representative of the three distinct phenotypes observed; these are referred to as Type I $(A)$, II $(B)$, or III $(C)$. In the majority 
Table 1. Outward $\mathrm{K}^{+}$currents in wild-type and transfected SCG neurons ${ }^{a}$

\begin{tabular}{|c|c|c|c|c|c|c|c|c|c|}
\hline \multirow{2}{*}{\multicolumn{2}{|c|}{ Phenotype }} & \multicolumn{3}{|l|}{ Wild type } & \multicolumn{3}{|l|}{$\mathrm{Kv} 4.2 \mathrm{~W} 362 \mathrm{~F}$} & \multicolumn{2}{|l|}{$\mathrm{Kv} 4.2$} \\
\hline & & Type I & Type II & Type III & A & $\mathrm{B}$ & $\mathrm{C}$ & Type I & Type II \\
\hline \multicolumn{2}{|c|}{ Peak current density } & $252 \pm 20$ & $259 \pm 22$ & $211 \pm 18$ & $162 \pm 21$ & $289 \pm 31$ & $244 \pm 35$ & $249 \pm 27$ & $291 \pm 37$ \\
\hline & density $(\mathrm{pA} / \mathrm{pF})$ & $81 \pm 11$ & $111 \pm 21$ & & & & $64 \pm 20$ & $127 \pm 9^{+}$ & $136 \pm 16^{+}$ \\
\hline & $\tau(\mathrm{msec})$ & $121 \pm 14$ & $95 \pm 8$ & & & & $190 \pm 18$ & $87 \pm 10$ & $70 \pm 8$ \\
\hline & density $(\mathrm{pA} / \mathrm{pF})$ & & $45 \pm 3$ & & & $67 \pm 15$ & & & $57 \pm 21$ \\
\hline & $\tau(\mathrm{msec})$ & & $480 \pm 21$ & & & $490 \pm 31$ & & & $472 \pm 8$ \\
\hline \multirow[t]{2}{*}{$I_{\mathrm{K}}$} & density $(\mathrm{pA} / \mathrm{pF})$ & $108 \pm 12$ & $64 \pm 9 *$ & $136 \pm 11$ & $111 \pm 22$ & $157 \pm 25^{* *}$ & $115 \pm 7$ & $78 \pm 17^{++}$ & $67 \pm 2$ \\
\hline & $\tau(\mathrm{msec})$ & $2560 \pm 187$ & $2800 \pm 193$ & $2200 \pm 176$ & $2050 \pm 235$ & $2473 \pm 254$ & $2368 \pm 197$ & $2126 \pm 518$ & $2151 \pm 195$ \\
\hline \multirow{2}{*}{\multicolumn{2}{|c|}{ density $(\mathrm{pA} / \mathrm{pF})$}} & $74 \pm 5$ & $45 \pm 5^{*}$ & $79 \pm 6$ & $65 \pm 9$ & $72 \pm 15$ & $68 \pm 15$ & $40 \pm 6^{++}$ & $38 \pm 17$ \\
\hline & & 30 & 9 & 4 & 18 & 7 & 6 & 11 & 5 \\
\hline
\end{tabular}

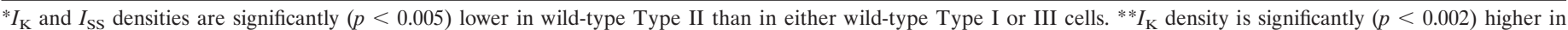

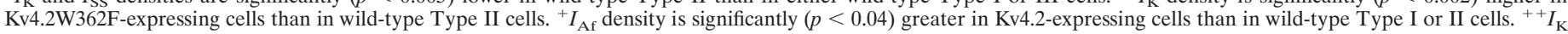
and $I_{\mathrm{SS}}$ densities are also significantly $(p<0.005)$ lower in Kv4.2-expressing cells than in wild-type Type I cells (Table 1$)$.

${ }^{a}$ All values are mean $\pm \mathrm{SEM}$; current densities determined at $+50 \mathrm{mV} ; n=$ number of cells.

( $>90 \%$ ) of cells studied, currents similar to those in Figure 1, $A$ and $B$, were recorded. There is a prominent rapid component of current decay in these (Type I and Type II) cells (right panels), consistent with the presence of a fast transient outward " $\mathrm{A}$ " $\mathrm{K}^{+}$current (Belluzzi et al., 1985a; Storm, 1990; McFarlane and Cooper, 1992). This current is referred to here as $I_{\mathrm{A} \text {,fast }}$, or $I_{\mathrm{Af}}$, to distinguish it from another, more slowly inactivating, transient outward $\mathrm{K}^{+}$ current $I_{\mathrm{A} \text {,slow }}\left(I_{\mathrm{As}}\right)$ that is also seen in some SCG cells (see below). Analysis of the outward $\mathrm{K}^{+}$currents evoked during long depolarizations in Type I SCG cells (Fig. $1 A$, right panel) revealed that current decay is well described by the sum of two exponentials, with decay time constants $\left(\tau_{\text {decay }}\right)$ that differ by more than an order of magnitude, and a noninactivating steady-state current (see below). The mean $\pm \operatorname{SEM} \tau_{\text {decay }}(n=30)$ determined for the fast and slow components of decay in these (Type I) cells were $121 \pm 14$ and $2560 \pm 187 \mathrm{msec}$, respectively (Table 1 ). Neither time constant displays any appreciable voltage dependence (data not shown). Two $\mathrm{K}^{+}$currents with similar $\tau_{\text {decay }}$ values have been described previously in rat sympathetic neurons and were assumed to reflect the expression of distinct $\mathrm{K}^{+}$channels (McFarlane and Cooper, 1992). The rapidly inactivating current has been referred to as $I_{\mathrm{A}}$, or $I_{\text {Af }}$ (Freshi, 1983; Galvan and Sedlmeir, 1984; Belluzzi et al., 1985a; Nerbonne et al., 1986; McFarlane and Cooper, 1992; Wang and McKinnon, 1995), and the slowly inactivating current has been given various names, including $I_{\mathrm{K}}$ (Galvan and Sedlmeir, 1984; Belluzzi et al., 1985b; Nerbonne and Gurney, 1989) and $I_{\text {A,slow }}$ (McFarlane and Cooper, 1992). The very slowly decaying current component $\left(\tau_{\text {decay }}=2560 \pm 187 \mathrm{msec}\right)$ is referred to here as $I_{\mathrm{K}}$ to emphasize the slow inactivation kinetics and to distinguish this conductance pathway from $I_{\text {As }}$ (see below).

Although the waveforms of the currents in individual (Type I) SCG cells are similar, the densities of $I_{\mathrm{Af}}$ and $I_{\mathrm{K}}$ vary considerably. For example, $I_{\mathrm{Af}}$ density at $+50 \mathrm{mV}$ ranged from 70 to $208 \mathrm{pA} / \mathrm{pF}$, with a mean \pm SEM of $81 \pm 11 \mathrm{pA} / \mathrm{pF}(n=30)$ (Table 1$)$. Similarly, $I_{\mathrm{K}}$ densities at $+50 \mathrm{mV}$ in Type I cells varied considerably, ranging from 83 to $258 \mathrm{pA} / \mathrm{pF}$ with a mean $\pm \mathrm{SEM}$ of $108 \pm$ $12 \mathrm{pA} / \mathrm{pF}$ (Table 1 ). The density of the noninactivating $\mathrm{K}^{+}$current component remaining at the end of $6 \mathrm{sec}$ voltage steps (Fig. 1), $I_{\mathrm{SS}}$ (steady-state), is also variable; at $+50 \mathrm{mV}$, for example, $I_{\mathrm{SS}}$ density ranged from 35 to $127 \mathrm{pA} / \mathrm{pF}$, with a mean $\pm \mathrm{SEM}$ of $74 \pm 5 \mathrm{pA} / \mathrm{pF}$ $(n=30)$ (Table 1).

In some (9) of the $43 \mathrm{SCG}$ cells studied, outward $\mathrm{K}^{+}$current waveforms similar to those displayed in Figure $1 B$ were observed. In these (Type II) cells, the decay phases of the outward $\mathrm{K}^{+}$ currents were not well described by biexponential functions, and three exponentials were required to adequately describe the data. The mean \pm SEM $\tau_{\text {decay }}$ values derived from these fits were $95 \pm$ $8,480 \pm 21$, and $2800 \pm 193 \mathrm{msec}$ (Table 1$)$. The fast $\tau_{\text {decay }}(95 \pm$ $8 \mathrm{msec})$ and the very slow $\tau_{\text {decay }}(2800 \pm 193 \mathrm{msec})$ are not significantly different from those determined for $I_{\mathrm{Af}}$ and $I_{\mathrm{K}}$, respectively, in Type I cells. It is assumed, therefore, that these time constants also reflect expression of $I_{\mathrm{Af}}$ and $I_{\mathrm{K}}$ in Type II cells (see below). The component of current inactivation in Type II cells with a $\tau_{\text {decay }}=480 \pm 21 \mathrm{msec}$ is referred to as $I_{\mathrm{A} \text {,slow }}$, or $I_{\mathrm{As}}$, and is assumed to reflect the expression of a novel conductance pathway, distinct from $I_{\mathrm{A}, \text { fast }}, I_{\mathrm{K}}$, and $I_{\mathrm{SS}}$ (see below and Discussion). Although $I_{\mathrm{Af}}$ densities are similar in Type I and Type II cells, the densities of $I_{\mathrm{K}}$ and $I_{\mathrm{SS}}$ are significantly $(p<0.005)$ lower in Type II than in Type I cells (Table 1).

In the other four (of 43 or $\sim 9 \%$ ) SCG cells (Type III) studied, no rapidly inactivating $\mathrm{K}^{+}$currents (similar to $I_{\mathrm{Af}}$ and/or $I_{\mathrm{As}}$ ) were evident (Fig. 1C). The decay phases of the outward currents in these cells were well described by a single exponential with a mean \pm SEM $\tau_{\text {decay }}$ of $2200 \pm 176 \mathrm{msec}$ (Table 1$)$. Peak outward $\mathrm{K}^{+}$current densities in Type III cells, which lack both $I_{\mathrm{Af}}$ and $I_{\mathrm{As}}$ (Table 1), are lower than in Type I and II cells (Table 1). In addition, in Type III cells, $I_{\mathrm{SS}}$ contributes substantially more to the peak outward current than does $I_{\mathrm{SS}}$ in Type I or II cells (Table 1). In other respects, however, the properties of Type III cells are indistinguishable from Type I and II cells. The mean \pm SEM whole-cell membrane capacitances and input resistances, for example, were $33 \pm 3 \mathrm{pF}$ and $0.52 \pm 0.08 \mathrm{G} \Omega$ for the cells with $I_{\mathrm{Af}}(n=39)$, and $25 \pm 2 \mathrm{pF}$ and $0.60 \pm 0.04 \mathrm{G} \Omega$ for the cells lacking $I_{\text {Af }}(n=4)$.

\section{$I_{\text {Af }}$ is selectively attenuated in SCG neurons expressing Kv4.2W362F}

On the basis of the kinetic properties of $I_{\mathrm{Af}}$ and the sensitivity of this current to 4-AP, it seemed reasonable to suggest that this conductance pathway reflects the expression of Kv $4 \alpha$-subunits. Consistent with this hypothesis, previous studies have documented the expression of Kv4.1, Kv4.2, and Kv4.3 mRNAs in SCG neurons (Dixon and McKinnon, 1996; Pankevych et al., 1999). In addition, immunohistochemical experiments with anti-Kv4 $\alpha$-subunit-specific antibodies reveal the expression of these subunits in isolated SCG neurons (Fig. 2). As evident in Figure $2 A$, for example, Kv4.2 expression is readily detected in the cell bodies of isolated SCG neurons. The expression pattern for Kv4.3 is distinct (from that of Kv4.2): Kv4.3 staining is seen throughout the processes of isolated SCG neurons (Fig. 2B). In addition, the anti-Kv4.3 labeling appears to be punctate (Fig. $2 B$ ), suggesting "clustering" of Kv4.3-encoding $\mathrm{K}^{+}$channels. A similar staining pattern is seen with an anti-Kv4 pan antibody, which also strongly labels cell bodies and proximal processes (Fig. 2C).

To test the hypothesis that $\mathrm{Kv} 4 \alpha$-subunits underlie $I_{\text {Af }}$ in SCG neurons, cells were transfected with a pore mutant of Kv4.2, Kv4.2W362F, that functions as a dominant negative (Barry et al., 1998). Previous studies have shown that coexpression of 

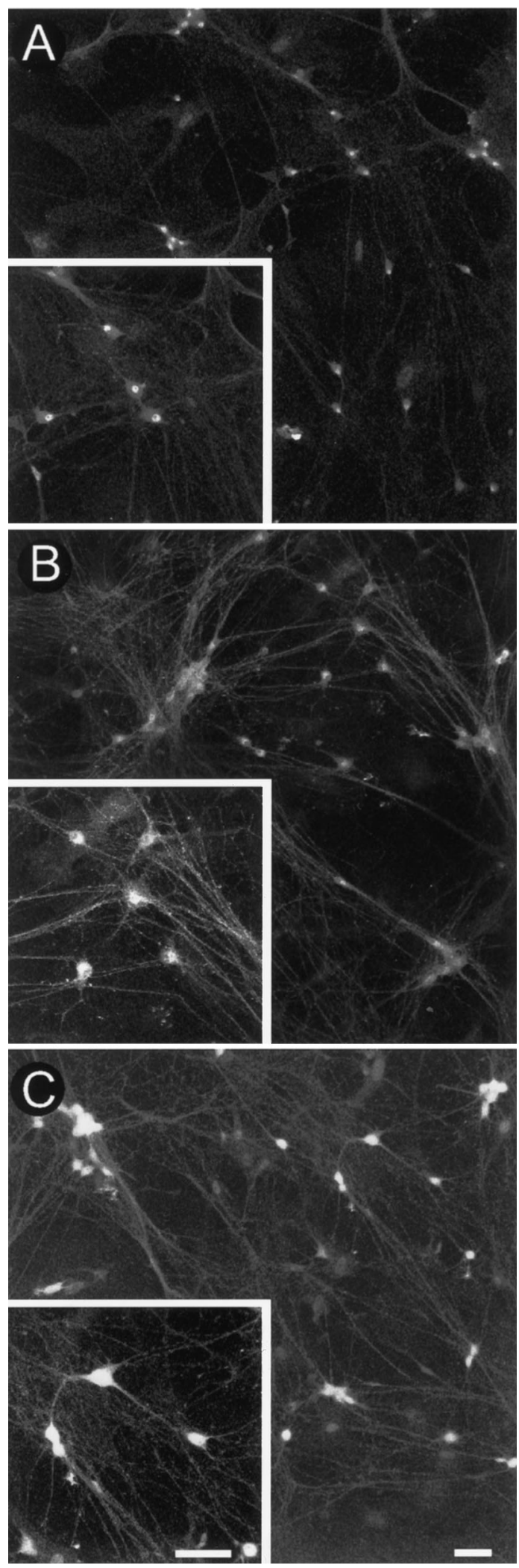

Figure 2. Expression of Kv4 $\alpha$-subunits in SCG neurons. Isolated wildtype SCG neurons were examined immunohistochemically $48 \mathrm{hr}$ after plating, as described in Materials and Methods. Cultures were stained with anti-Kv4.2 $(A)$, anti-Kv4.3 $(B)$, and a pan-Kv4 antibody $(C)$. Both Kv4.2 and $\mathrm{Kv} 4.3$ are readily detected in SCG neurons; Kv4.2 is localized to the cell bodies and proximal processes, whereas Kv4.3 is also detected in more distal processes. In addition, the anti-Kv4.3 appears more punctate. Scale bars, $50 \mu \mathrm{m}$.
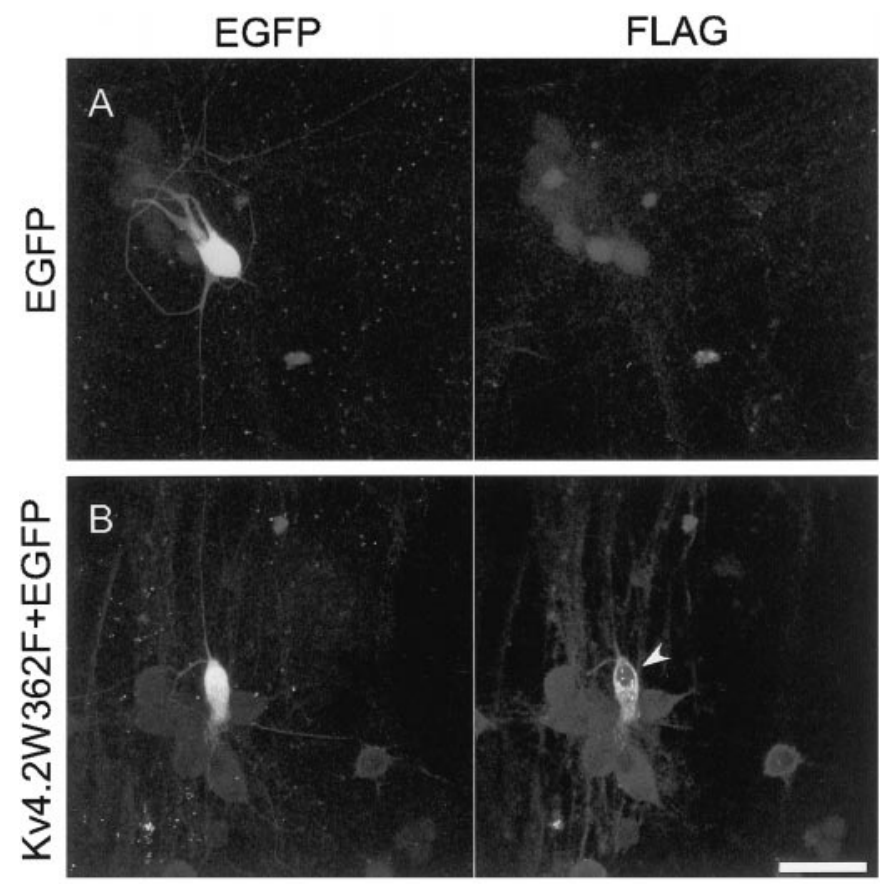

Figure 3. Immunohistochemical detection of Kv4.2W362F-FLAG in transfected SCG neurons. Isolated SCG neurons, transfected with EGFP alone $(A)$ or with $\mathrm{Kv} 4.2 \mathrm{~W} 362 \mathrm{~F}-\mathrm{FLAG}$ and $\mathrm{EGFP}(B)$ using the gene gun, were fixed and stained $24 \mathrm{hr}$ later (see Materials and Methods). $A, B$, EGFP fluorescence (left panels) and Cy3 fluorescence (right panels) images of the same field. Anti-FLAG staining is only evident in cultures transfected with Kv4.2W362F-FLAG expression (compare right panels in $A$ and $B$ ). In addition, EGFP expression correlates with Kv4.2W362F (compare left and right panels in $B$ ). Scale bar, $50 \mu \mathrm{m}$.

Kv4.2W362F with either Kv4.2 or Kv4.3 attenuates current amplitudes relative to cells expressing (wild-type) Kv4.2 or Kv4.3 alone (Barry et al., 1998). In the experiments here, beads were coated either with cDNA constructs encoding Kv4.2W362F and EGFP or with the EGFP cDNA alone, and cells were transfected using the biolistics gene gun (see Materials and Methods). Within $24 \mathrm{hr}$ of transfection, EGFP expression was readily detected under epifluorescence illumination (Fig. $3 A$ ); $\sim 10 \%$ of the cells in these cultures were EGFP positive. To determine whether EGFP-positive cells in cultures exposed to beads coated with Kv4.2W362F (and EGFP) also express the transgene, the cultures were fixed $\sim 48 \mathrm{hr}$ after transfection and probed with the anti-FLAG M2 antibody. These experiments revealed that all EGFP-positive cells in these cultures $(n=112)$ also express Kv4.2W362F-FLAG. An example of an EGFP-positive, Kv4.2W362F-positive cell is illustrated in Figure $3 B$. As is evident, the FLAG staining appears to be predominantly on the cell surface (arrow), whereas EGFP expression is detected in the cytosol (Fig. $3 B$ ). In addition, EGFP appears to fill the entire cell (Fig. 3B).

Representative whole-cell voltage-gated outward $\mathrm{K}^{+}$current waveforms recorded from SCG neurons expressing Kv4.2W362F (and EGFP) are presented in Figure 4. Control experiments revealed that the outward $\mathrm{K}^{+}$currents in cells expressing EGFP alone are indistinguishable from those in wild-type cells (Fig. 1). The waveforms of the outward $\mathrm{K}^{+}$currents in cells expressing Kv4.2W362F (Fig. 4), however, are very different from those recorded from wild-type cells. Specifically, the rapid component of current decay, $I_{\mathrm{Af}}$, that is prominent in wild-type Type I (Fig. 1A) and Type II (Fig. $1 B$ ) SCG cells appears to be missing in (all) cells expressing Kv4.2W362F (Fig. 4). In contrast to the results obtained on wild-type and EGFP-expressing cells (Table 1), the decay phases of the outward currents in the majority $(18$ of $31,58 \%)$ of Kv4.2W362F-expressing cells (Fig. 4A) were well described by a single exponential $\left(\tau_{\text {decay }}=2205 \pm 235 \mathrm{msec}\right)$ and a steady-state outward current (Table 1). The waveforms of the currents in these 

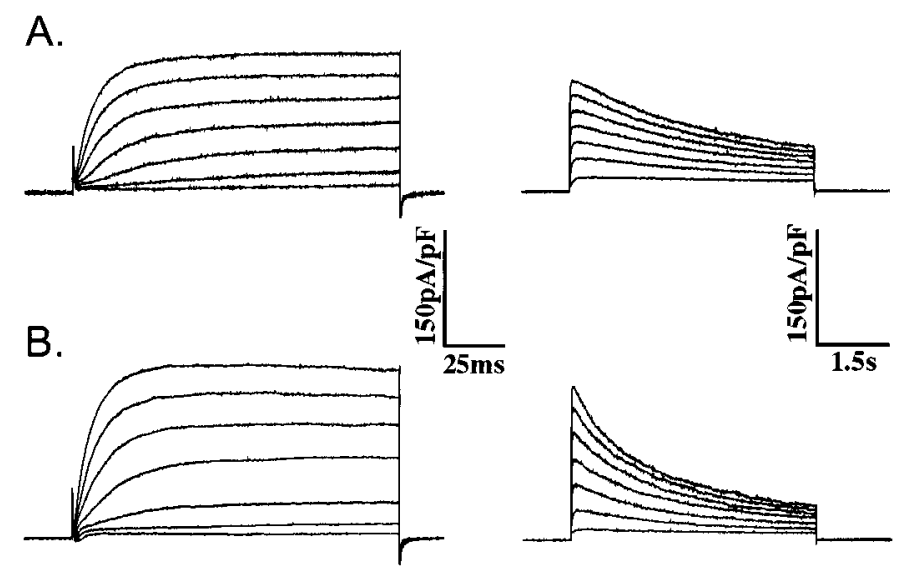

C.
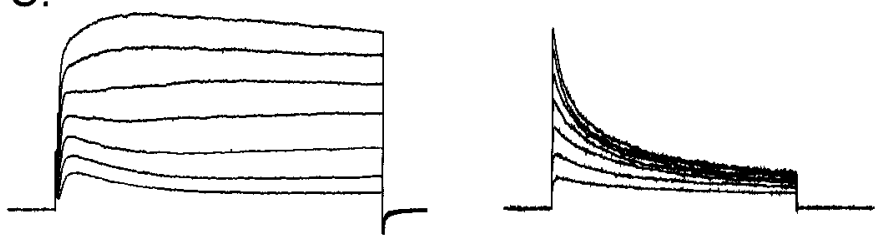

Figure 4. $I_{\mathrm{Af}}$ is eliminated in SCG neurons expressing Kv4.2W362FFLAG. Whole-cell depolarization-activated outward $\mathrm{K}^{+}$currents were recorded from isolated SCG neurons transfected with Kv4.2W362F-FLAG as described in the legend to Figure 1. The left and right panels in $A-C$ were recorded from the same cell. The waveforms of the currents recorded from cells expressing Kv4.2W362F are distinct from those recorded from wildtype cells or from cells expressing EGFP alone (Fig. 1). In the majority of cells $(A, B)$, current activation and inactivation are slow, consistent with the absence of $I_{\text {Af }}$ (see Results). In a small subset of Kv4.2W362F-expressing cells $(C)$, a rapid component of decay with a mean \pm SEM $\tau_{\text {decay }}$ that is not significantly different from that determined for $I_{\mathrm{Af}}$ in wild-type Type I SCG cells (Table 1) is evident (see Results).

cells (Fig. 4A) are indistinguishable from wild-type Type III cells (Fig. $1 C$ ), suggesting expression of only $I_{\mathrm{K}}$ and $I_{\mathrm{SS}}$ (Table 1$)$. In the remaining Kv4.2W362F-expressing cells (Fig. 4B,C), two exponentials were required to fit the decay phases of the currents. In 7 of 31 cells, current waveforms similar to those in Figure $4 B$ were recorded. Analysis of the decay phases of the outward $\mathrm{K}^{+}$currents in these cells provided mean \pm SEM $\tau_{\text {decay }}$ values of $490 \pm 31$ and $2473 \pm 254 \mathrm{msec}$, consistent with the presence of $I_{\mathrm{As}}$ and $I_{\mathrm{K}} ; I_{\mathrm{SS}}$ is also evident in these cells (Table 1). Although these (Fig. 4B) cells represent a novel (nonphysiological) class of SCG neurons, the percentage $(22 \%)$ of cells with this phenotype and the distribution of current densities suggest that these are Type II cells that lack the fast transient current component, $I_{\mathrm{Af}}$, attributable to the expression of Kv4.2W362F. Interestingly, the densities of $I_{\mathrm{K}}$ and $I_{\mathrm{SS}}$ in these cells (Table 1$)$ are significantly $(p<.002)$ higher than in wild-type Type II cells (Table 1 ), suggesting that $I_{\mathrm{K}}$ and $I_{\mathrm{SS}}$ are upregulated in Type II cells when $I_{\text {Af }}$ is eliminated (see Discussion).

In the remaining Kv4.2W362F-expressing SCG cells $(n=6)$, a rapid component of outward current decay is detected (Fig. 4C), suggesting that $I_{\text {Af }}$ is unaffected by $\mathrm{Kv} 4.2 \mathrm{~W} 362 \mathrm{~F}$ expression in a subset of SCG cells. Analysis of the currents in records such as those in Figure $4 C$ revealed that the mean \pm SEM density of this component is lower and the mean \pm SEM $\tau_{\text {decay }}$ is longer than those determined for $I_{\text {Af }}$ in wild-type Type I and II cells (Table 1). These observations suggest that there are actually two components of $I_{\mathrm{Af}}$, only one of which is encoded by Kv4 $\alpha$-subunits (and therefore affected by $\mathrm{Kv} 4.2 \mathrm{~W} 362 \mathrm{~F}$ expression) or, alternatively, that a novel current is upregulated in this subset of SCG cells (Fig. $4 C$ ) when $I_{\mathrm{Af}}$ is eliminated. The time constants of inactivation of currents in records such as those in Figure $4 C$ varied over the range $138-249 \mathrm{msec}$. Although this range is similar to that $(60-208 \mathrm{msec})$ observed in wild-type Type I and II cells, it is narrower, and the distributions of time constants are quite different (Fig. 5). In the

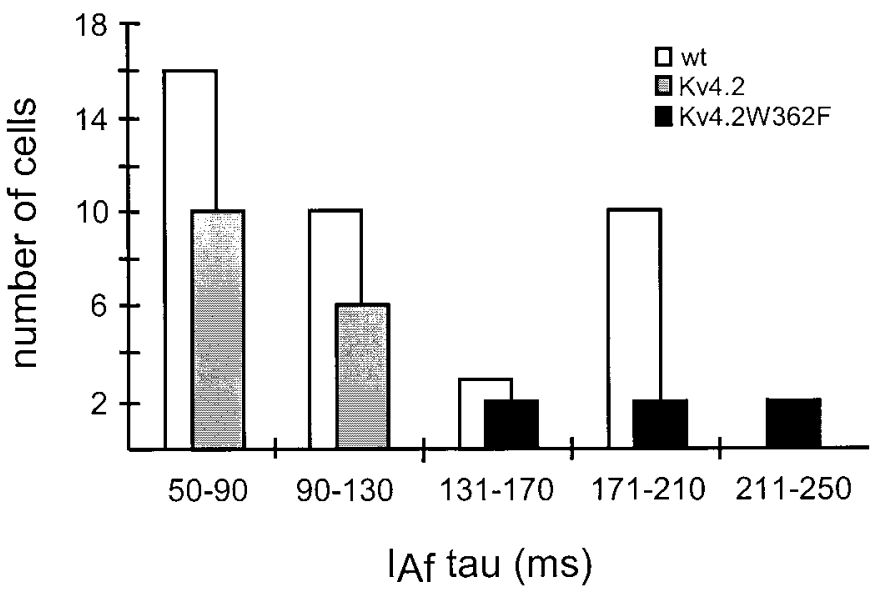

Figure 5. Two components of $I_{\mathrm{Af}}$ in SCG neurons. The time constants of inactivation of the rapid component of current decay were determined in wild-type, Kv4.2W362F-, and Kv4.2-expressing SCG cells, as described in Materials and Methods. The $\tau_{\text {decay }}$ values were binned in $40 \mathrm{msec}$ increments for comparison purposes, and, as is evident, the distributions of $\tau_{\text {decay }}$ values are distinct (see Results).

A. Phasic $(43 \%)$
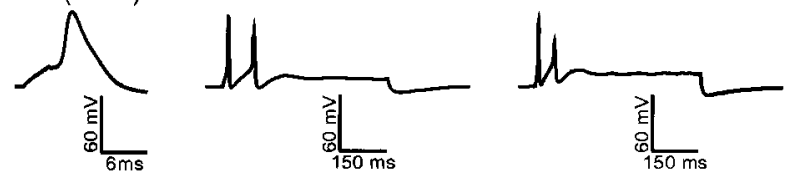

B. Adapting (32\%)
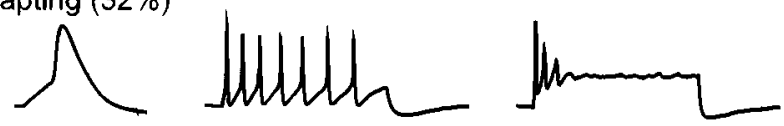

C. Tonic $(25 \%)$
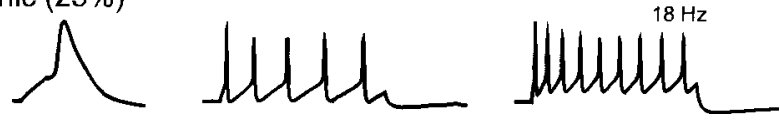

Figure 6. Distinct repetitive firing patterns in SCG neurons. Action potentials and repetitive firing patterns were recorded from isolated EGFPexpressing SCG neurons in response to brief or prolonged depolarizing current injections, as described in Materials and Methods. Current-clamp recordings from three representative cells are shown in $A-C$. In each cell, single action potentials were elicited by $1.5 \mathrm{msec}$ depolarizing current injections (left panels), and repetitive firing patterns were recorded in response to $500 \mathrm{msec}$ depolarizing currents injections of $100 \mathrm{pA}$ (middle panels) or $200 \mathrm{pA}$ (right panels). Based on the response(s) to the $500 \mathrm{msec}$ current injections, cells were classified as phasic $(A)$, adapting $(B)$, or tonic (C) (see Results and Table 2).

Kv4.2W362F-expressing cells, $\tau_{\text {decay }}$ values fall between 138 and $249 \mathrm{msec}$, whereas in wild-type cells, there appear to be two distinct groups of cells, i.e., those with $\tau_{\text {decay }}$ values in the 50-130 msec range $\left(26\right.$ of $39 ; 66 \%$ ) and those with $\tau_{\text {decay }}$ values between 131 and $210 \mathrm{msec}(13$ of 39; 33\%). These observations further suggest that only the faster current $\left(\tau_{\text {decay }} 50-130 \mathrm{msec}\right)$ is encoded by Kv4 $\alpha$-subunits (see Discussion).

\section{Action potential waveforms and repetitive firing in SCG neurons}

Subsequent experiments were aimed at evaluating the role of $I_{\mathrm{Af}}$ in shaping the waveforms of individual action potentials and in determining the repetitive firing properties of SCG neurons. Although the waveforms of the action potentials recorded from wildtype SCG neurons are similar, the responses to prolonged (500 $\mathrm{msec}$ ) depolarizing current injections are distinct (Fig. $6 A-C$ ). In $\sim 45 \%$ of the SCG cells examined, phasic firing was observed, i.e., cells fire one or two action potentials in response to prolonged current injections (Fig. 6 A, middle panel), and the number of action potentials elicited is unaffected by increasing the amplitude of the 
Table 2. Resting and active membrane properties of SCG neurons ${ }^{a}$

\begin{tabular}{|c|c|c|c|c|c|c|c|}
\hline Phenotype & $R_{\text {in }}(\mathrm{G} \Omega)$ & $V_{\mathrm{m}}(\mathrm{mV})$ & $\mathrm{AP}_{\text {Thresh }}(\mathrm{pA})$ & APA $(\mathrm{mV})$ & $\mathrm{APD}_{50}(\mathrm{msec})$ & $\mathrm{APD}_{90}(\mathrm{msec})$ & $n$ \\
\hline All cells & $0.34 \pm 0.03$ & $-48 \pm 1$ & $46 \pm 5$ & $82 \pm 4$ & $3.66 \pm 0.14$ & $5.92 \pm 0.20$ & 28 \\
\hline Phasic & $0.26 \pm 0.02$ & $-45 \pm 2$ & $67 \pm 1$ & $80 \pm 5$ & $4.18 \pm 0.24$ & $6.55 \pm 0.34$ & 12 \\
\hline Adapting & $0.60 \pm 0.06^{* *}$ & $-48 \pm 1$ & $24 \pm 2^{*}$ & $87 \pm 3$ & $3.57 \pm 0.20$ & $5.96 \pm 0.20$ & 9 \\
\hline Tonic & $0.22 \pm 0.02$ & $-52 \pm 1$ & $42 \pm 2$ & $91 \pm 3$ & $2.97 \pm 0.03^{++}$ & $4.87 \pm 0.20^{+}$ & 7 \\
\hline
\end{tabular}

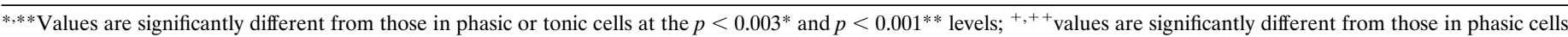
$\left(p<0.001^{++}\right)$and from those in phasic or adapting cells $\left(p<0.003^{+}\right)$.

${ }^{a}$ All values are means \pm SEM.

injected current (Fig. 6A, right panel). Repetitive firing was observed, however, in the remaining $\sim 55 \%$ of the SCG cells studied (Fig. $6 B, C$ ). In approximately half of these cells, low amplitude current injections produce repetitive firing, and the frequency of firing decreases as a function of time after the onset of the current injection, i.e., these cells "adapt" (Fig. 6B, middle panel). When the amplitude of the injected current is increased, adapting cells become refractory and firing ceases, despite the maintained current injection (Fig. 6B, right panel). The remaining subset of cells displayed "tonic" activity, firing regularly spaced action potentials in response to prolonged depolarizing current injections (Fig. $6 C$, middle panel). In addition, in tonic cells, the frequency of firing increases with the amplitude of the injected current (Fig. 6C, right panel). No refractoriness is evident in tonic cells during current injections ranging from 20 to $300 \mathrm{pA}$, clearly distinguishing these cells from both phasic and adapting neurons.

The properties of phasic, adapting, and tonic cells are quite similar, despite the marked differences in repetitive firing patterns (Fig. 6). Resting membrane potentials and action potential amplitudes, for example, are indistinguishable in phasic, adapting, and tonic SCG cells (Table 2). Action potentials recorded from tonic cells, however, are significantly $(p<0.001)$ briefer than in either phasic or adapting cells (Table 2 ). At $90 \%$ repolarization, for example, the mean \pm SEM action potential duration $\left(\mathrm{APD}_{90}\right)$ in tonic cells is $4.87 \pm 0.20 \mathrm{msec}$, whereas mean $\pm \mathrm{SEM} \mathrm{APD}_{90}$ values determined in phasic and tonic cells were $5.96 \pm 0.20$ and $6.55 \pm$ $0.34 \mathrm{msec}$, respectively (Table 2 ). In addition, the input resistances of adapting cells are significantly $(p<0.001)$ higher than those of either phasic or tonic cells (Table 2). Consistent with this difference in input resistance, the mean \pm SEM current threshold $(24 \pm 2 \mathrm{pA})$ for action potential generation is significantly $(p<0.003)$ lower in adapting cells than in phasic $(67 \pm 1 \mathrm{pA})$ or tonic $(42+2 \mathrm{pA})$ cells (Table 2). Subsequent experiments were aimed at determining directly the role of $I_{\mathrm{Af}}$ in mediating the phasic, tonic, and adapting firing patterns of SCG neurons by examining the effects of $\mathrm{Kv} 4.2 \mathrm{~W} 362 \mathrm{~F}$ expression on action potentials and repetitive firing.

\section{Elimination of $I_{A f}$ increases excitability (and percentage) of "adapting" SCG cells}

Previous pharmacological studies suggest a primary role for $I_{\mathrm{Af}}$ in the regulation of excitability and in action potential repolarization in SCG neurons (Galvan and Sedlmeir, 1984; Belluzzi et al., 1985a; Nerbonne and Gurney, 1989). Application of 4-AP, often assumed to be a specific blocker of $I_{\mathrm{Af}}$, for example, reportedly increases the excitability of SCG neurons (Galvan and Sedlmeir, 1984). In the presence of 4-AP, the current threshold for action potential generation and the latency to firing are reduced, and action potentials are prolonged (Galvan and Sedlmeir, 1984; Belluzzi et al., 1985a; Nerbonne and Gurney, 1989). In some studies, the input resistances of SCG neurons were also reportedly increased after exposure to 4-AP (Galvan and Sedlmeir, 1984; Belluzzi et al., 1985a). If all of these effects are attributable to loss of $I_{\mathrm{Af}}$, then similar changes in excitability and action potential durations would be expected to be observed in SCG neurons expressing Kv4.2W362F (and lacking $I_{\text {Af }}$.

Representative current-clamp recordings from SCG cells expressing $\mathrm{Kv} 4.2 \mathrm{~W} 362 \mathrm{~F}$ are presented in Figure 7. As in recordings

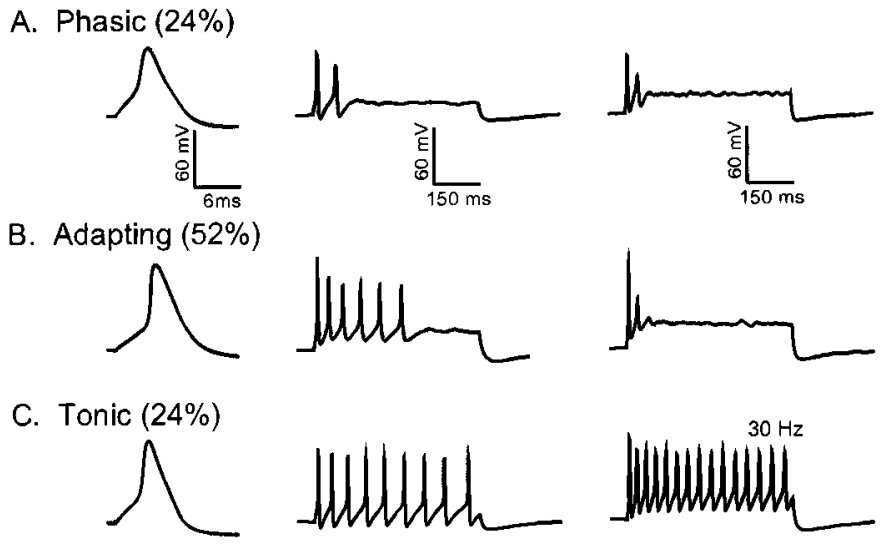

Figure 7. Elimination of $I_{\mathrm{Af}}$ increases the percentage of adapting cells. Action potentials and repetitive firing patterns were recorded, as described in the legend to Figure 6, from isolated SCG neurons expressing $\mathrm{Kv} 4.2 \mathrm{~W} 362 \mathrm{~F}$. Records from three representative cells are shown in $A-C$. As in wild-type cells (Fig. 6), the phasic, adapting, and tonic firing patterns are observed in Kv4.2W362F-expressing cells. However, the percentage of adapting cells is increased markedly, and the percentage of phasic cells is decreased (Table 3 ) relative to the distribution of firing patterns in wildtype cells (Table 2).

from wild-type (or EGFP-expressing) SCG cells, the phasic, adapting, and tonic firing patterns were also observed in SCG neurons expressing Kv4.2W362F. In contrast to control cells, however, the majority $(52 \%)$ of Kv4.2W362F-expressing cells are adapting (Fig. $7 B)$. This increase in the number of adapting cells reflects a decline in the fraction of neurons displaying the phasic phenotype from $43 \%$ of wild-type neurons (Fig. 6B, Table 2) to $24 \%$ of Kv4.2W362Fexpressing cells (Fig. $7 B$, Table 3 ). The percentage of tonic cells, in contrast, is unaffected by loss of $I_{\mathrm{Af}}$ : $\sim 25 \%$ of wild-type (Fig. $6 C$, Table 2) and Kv4.2W362F-expressing (Fig. 7C, Table 3) cells fire tonically. These observations suggest that low $I_{\text {Af }}$ density correlates with the adapting phenotype (see Discussion). In addition to the redistribution of cells, the input resistances of phasic and tonic cells expressing Kv4.2W362F (Table 3) are significantly $(p<0.001)$ higher than in wild-type (phasic and tonic) cells (Table 2), whereas the input resistances in adapting cells expressing Kv4.2W362F were not significantly different from wild-type adapting cells (Table 2). Indeed, the input resistances of Kv4.2W362F-expressing phasic, adapting, and tonic SCG cells are similar (Table 3). Consistent with this increase in input resistance, the current thresholds for firing single action potentials (and trains) in Kv4.2W362F-expressing phasic and tonic cells are significantly $(p<0.003)$ lower (Table 3$)$ than in wild-type (phasic and tonic) cells (Table 2).

In contrast to the marked effects on excitability, action potential durations are not affected measurably by elimination of $I_{\text {Af }}$ (Table 3 ). These observations suggest that $I_{\text {Af }}$ does not play a prominent role in determining action potential durations in SCG neurons (see Discussion). Tonic cells expressing Kv4.2W362F, however, fire at higher frequencies (Fig. 7) than their wild-type counterparts (Fig. 6) in response to current injections of the same amplitude. In response to a $200 \mathrm{pA}$ current injection, for example, wild-type tonic 
Table 3. Expression of Kv4.2W362F increases input resistance and the number of adapting SCG neurons ${ }^{a}$

\begin{tabular}{|c|c|c|c|c|c|c|c|}
\hline Phenotype & $R_{\text {in }}(\mathrm{G} \Omega)$ & $V_{\mathrm{m}}(\mathrm{mV})$ & $\mathrm{AP}_{\text {Thresh }}(\mathrm{pA})$ & APA $(m V)$ & $\mathrm{APD}_{50}(\mathrm{msec})$ & $\mathrm{APD}_{90}(\mathrm{msec})$ & $n$ \\
\hline All cells & $68 \pm 0.08$ & $-49 \pm 1$ & $28 \pm 2$ & $90 \pm 2$ & $3.54 \pm 0.27$ & $5.59 \pm 0.22$ & 25 \\
\hline Phasic & $0.64 \pm 0.14^{*}$ & $-47 \pm 2$ & $30 \pm 7 * *$ & $82 \pm 3$ & $3.63 \pm 0.44$ & $6.07 \pm 0.33$ & 6 \\
\hline Adapting & $0.76 \pm 0.12$ & $-47 \pm 1$ & $26 \pm 3$ & $89 \pm 2$ & $3.47 \pm 0.14$ & $5.76 \pm 0.23$ & 13 \\
\hline Tonic & $0.60 \pm 0.09 * *$ & $-53 \pm 3$ & $27 \pm 2^{*}$ & $99 \pm 4$ & $2.90 \pm 0.09$ & $4.90 \pm 0.20^{+}$ & 6 \\
\hline
\end{tabular}

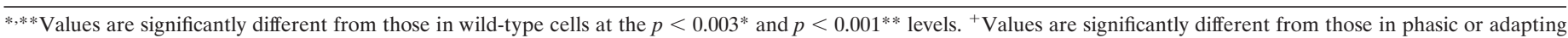
cells at the $p<0.01$ level.

${ }^{a}$ All values are means \pm SEM.

A. Phasic (36\%)
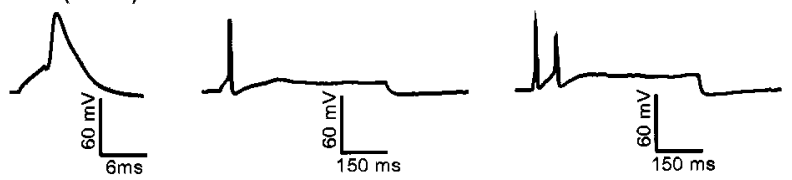

B. Adapting (14\%)
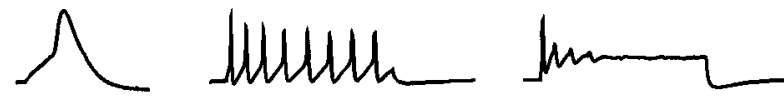

C. Tonic $(50 \%)$
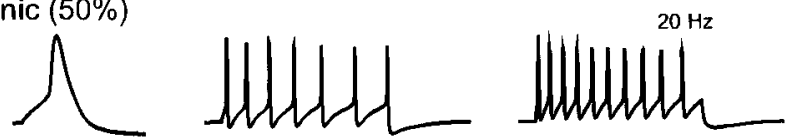

Figure 8. Increased $I_{\text {Af }}$ density decreases action potential durations and increases the percentage of tonic SCG neurons. Action potentials and repetitive firing patterns, recorded as described in the legend to Figure 6, were obtained from isolated SCG neurons $24 \mathrm{hr}$ after transfection with wild-type Kv4.2. Records from three representative cells are shown in $A-C$. As in wild-type cells, the phasic $(A)$, adapting $(B)$, and tonic $(C)$ firing patterns were seen in Kv4.2 overexpressing cells. In cultures overexpressing $\mathrm{Kv} 4.2$, however, the percentage of adapting cells is lower and the percentage of tonic cells is higher than seen in wild-type (Table 2) or Kv4.2W362Fexpressing (Table 3) SCG cells.

cells fire at mean \pm SEM frequencies of $15 \pm 1 \mathrm{~Hz}$, whereas Kv4.2W362F-expressing cells fire at $29 \pm 2 \mathrm{~Hz}$. The likely interpretation of this observation is the fact that the current thresholds for action potential generation are decreased in cells expressing Kv4.2W362F (Table 3) as compared with wild-type cells (Table 2).

\section{Increasing $\boldsymbol{I}_{\text {Af }}$ reduces the number of adapting cells}

The results of the experiments above suggest that low $I_{\text {Af }}$ density is an important determinant of the adapting phenotype. To further test this hypothesis, the effects of increasing $I_{\mathrm{Af}}$ density on the firing properties of SCG neurons were examined. In these experiments, SCG neurons were transfected with a construct encoding wild-type Kv4.2 (as well as EGFP), and current-clamp recordings were obtained from EGFP-positive cells. These experiments revealed firing patterns (Fig. 8) that are indistinguishable from those of wild-type (and EGFP-expressing) SCG neurons (Fig. 6), although the distribution of cells displaying the various firing patterns is quite distinct (Table 4). Half of the cells transfected with the Kv4.2 construct are tonic (Fig. $8 C$ ), only $14 \%$ of the cells are adapting (Fig. $8 B$ ), and the remaining $36 \%$ of the cells are phasic (Fig. $8 A$ ). There is a marked increase in tonic cells and a corresponding decrease in the number of adapting cells with overexpression of Kv4.2 (Fig. 8B, Table 4). The properties of the Kv4.2expressing cells that are adapting (Fig. $8 B$ ) are also distinct from those of wild-type adapting cells (Table 2) in that the current threshold for action potential generation is increased significantly $(p<0.003)$ by Kv4.2 expression (Table 4), consistent with a decrease in input resistance (Table 4). These results suggest that all adapting cells are converted to phasic or tonic cells as a function of $I_{\text {Af }}$ density (see Discussion). Analysis of the waveforms of evoked action potentials also revealed that $\mathrm{APD}_{50}$ values (Table 4) in Kv4.2-expressing phasic cells are significantly $(p<0.001)$ shorter than in wild-type phasic cells (Table 2). In contrast, mean action potential durations in adapting and tonic SCG cells overexpressing Kv4.2 are not significantly different from those in wild-type (adapting and tonic) SCG cells (compare Table 2 and Table 4).

Analysis of voltage-clamp recordings from EGFP-positive cells in Kv4.2-transfected cultures revealed that the density of $I_{\mathrm{Af}}$ is increased relative to the currents in wild-type (and EGFPexpressing) SCG neurons. In all cells expressing wild-type Kv4.2, a prominent fast transient current is evident (Fig. 9). Analysis of the decay phases of the outward currents revealed that inactivation is best described by the sum of two (Fig. 9A) or three (Fig. 9B) exponentials. The mean \pm SEM decay time constants derived from these fits are similar to those determined in wild-type I and II SCG cells (Table 1). No Type III neurons, which lack $I_{\mathrm{Af}}$ and $I_{\mathrm{As}}$ (Table $1)$, were seen among the cells expressing Kv4.2. In the majority $(69 \%)$ of the cells overexpressing $\mathrm{Kv} 4.2, I_{\mathrm{Af}}, I_{\mathrm{K}}$, and $I_{\mathrm{SS}}$ are detected (Table 1). The waveforms of the currents (Fig. 9A) are similar to those in wild-type I cells (Fig. $3 A$ ), although $I_{\text {Af }}$ density is significantly $(p<0.04)$ higher and $I_{\mathrm{K}}$ and $I_{\mathrm{SS}}$ densities are significantly $(p<0.005)$ lower than in wild-type Type I cells (Table 1). In the remaining Kv4.2-expressing cells, three exponentials were required to fit the decay phases of the outward currents. These cells (Fig. 9B) are similar to wild-type Type II cells, expressing $I_{\mathrm{Af}}, I_{\mathrm{As}}, I_{\mathrm{K}}$, and $I_{\mathrm{Ss}}$, although $I_{\mathrm{Af}}$ density is significantly $(p<$ 0.04 ) higher in the Kv4.2-expressing cells (Table 1).

\section{DISCUSSION}

\section{Kv4 $\alpha$-subunits underlie $I_{\text {Af }}$ in SCG neurons}

In the experiments here, four kinetically distinct voltage-gated $\mathrm{K}^{+}$ currents have been distinguished in SCG neurons: two transient currents, $I_{\mathrm{Af}}$ and $I_{\mathrm{As}}$, as well as a slowly inactivating current, $I_{\mathrm{K}}$, and a steady-state current, $I_{\mathrm{SS}}$ (Table 1 ). In addition, these currents are differentially distributed, and SCG cells have been classified as Type I, II, or III based on expression differences. Type I cells express $I_{\mathrm{Af}}, I_{\mathrm{K}}$, and $I_{\mathrm{SS}}$, whereas Type II cells express $I_{\mathrm{Af}}, I_{\mathrm{As}}, I_{\mathrm{K}}$, and $I_{\mathrm{SS}}$, and Type III cells express only $I_{\mathrm{K}}$ and $I_{\mathrm{SS}}$. There is considerable variability in current densities within each grouping (Table 1 ), and interestingly, $I_{\mathrm{K}}$ and $I_{\mathrm{SS}}$ densities are significantly $(p<0.005)$ lower in Type II cells (the only cells that express $\left.I_{\text {As }}\right)$ than in either Type I or III cells (Table 1).

In experiments aimed at testing the hypothesis that $\alpha$-subunits of the Kv4 subfamily of voltage-gated $\mathrm{K}^{+}$channels underlie $I_{\mathrm{Af}}$ in SCG neurons, the biolistics method (gene gun) was used to introduce a mutant Kv4.2 $\alpha$-subunit, Kv4.2W362F, that functions as a dominant negative (Barry et al., 1998), into these cells in vitro. Voltage-clamp recordings from Kv4.2W362F-expressing cells revealed that in the vast majority $(\sim 80 \%)$ of cells no fast transient outward currents $\left(I_{\mathrm{Af}}\right)$ were detected (Fig. 3, Table 1). The densities of the other currents, $I_{\mathrm{As}}, I_{\mathrm{K}}$, and $I_{\mathrm{SS}}$, are largely unaffected by $\mathrm{Kv} 4.2 \mathrm{~W} 362 \mathrm{~F}$ expression, although $I_{\mathrm{K}}$ density is significantly higher in the $I_{\mathrm{As}}$-expressing subset of these cells (Table 1, column B) than in wild-type Type II cells (Table 1). The simplest interpretation of these findings is that $I_{\text {Af }}$ is encoded by Kv $4 \alpha$-subunits in most SCG neurons. Consistent with this hypothesis, $I_{\mathrm{Af}}$ was evident in all cells expressing wild-type Kv4.2 (Fig. 9), and mean $I_{\text {Af }}$ density was significantly $(p<0.04)$ higher than in wild-type cells (Table 1$)$.

Nevertheless, a rapidly inactivating current remains in $\sim 20 \%$ (6 
Table 4. Overexpression of Kv4.2 reduces the input resistance and the number of adapting neurons ${ }^{a}$

\begin{tabular}{|c|c|c|c|c|c|c|c|}
\hline Phenotype & $R_{\mathrm{in}}(\mathrm{G} \Omega)$ & $V_{\mathrm{m}}(\mathrm{mV})$ & $\mathrm{AP}_{\text {Thresh }}(\mathrm{pA})$ & APA $(m V)$ & $\mathrm{APD}_{50}(\mathrm{msec})$ & $\mathrm{APD}_{90}(\mathrm{msec})$ & $n$ \\
\hline All cells & $0.35 \pm 0.05$ & $-52 \pm 1$ & $43 \pm 4$ & $92 \pm 2$ & $2.78 \pm 0.10$ & $4.87 \pm 0.17$ & 28 \\
\hline Phasic & $0.23 \pm 0.03$ & $-52 \pm 1$ & $58 \pm 9$ & $89 \pm 3$ & $2.87 \pm 0.15^{* *}$ & $5.05 \pm 0.25^{*}$ & 10 \\
\hline Adapting & $0.46 \pm 0.07^{+}$ & $-51 \pm 2$ & $39 \pm 4^{*}$ & $86 \pm 2$ & $3.03 \pm 0.20$ & $5.28 \pm 0.24$ & 4 \\
\hline Tonic & $0.29 \pm 0.04$ & $-51 \pm 1$ & $45 \pm 4$ & $95 \pm 2$ & $2.70 \pm 0.19$ & $4.75 \pm 0.24$ & 14 \\
\hline
\end{tabular}

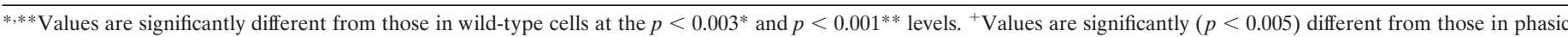
cells.

${ }^{a}$ All values are means \pm SEM.

\section{A. Type I}
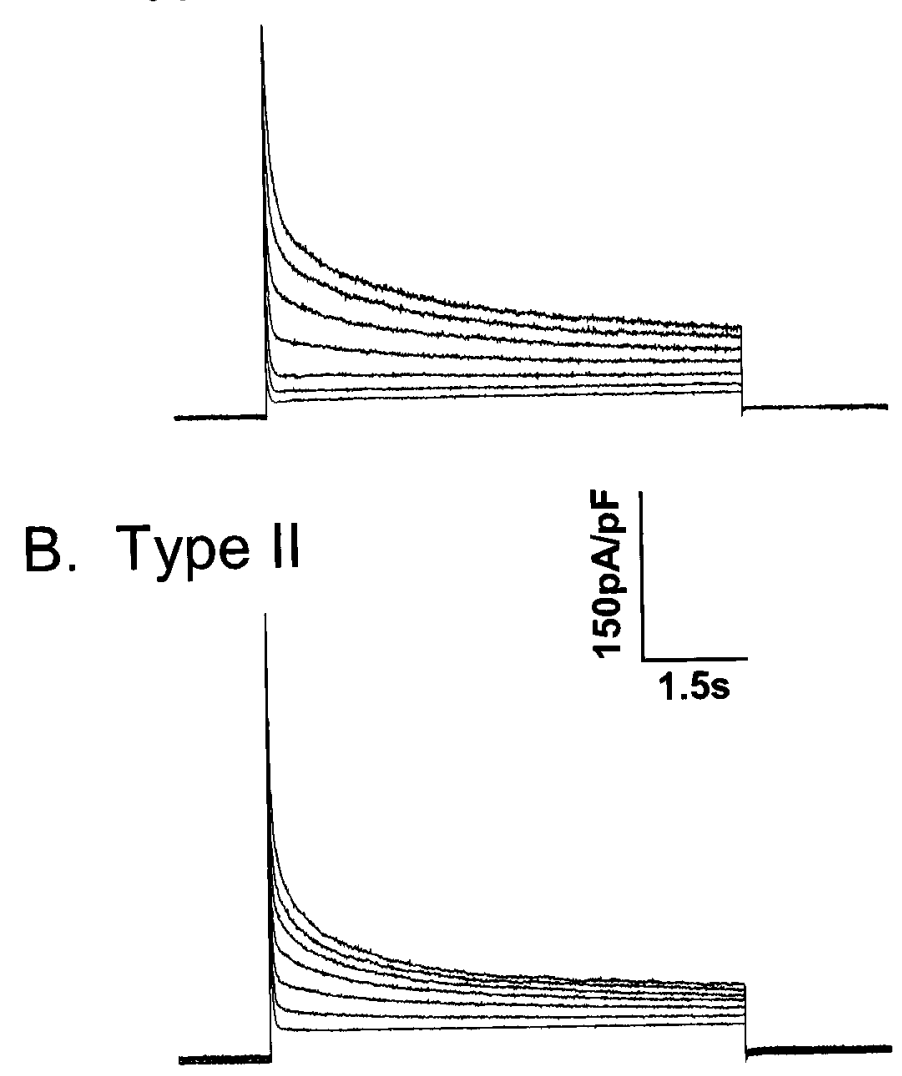

Figure 9. Overexpression of Kv4.2 increases $I_{\mathrm{Af}}$ density in SCG neurons. Isolated SCG neurons were transfected with Kv4.2 (and EGFP), and outward $\mathrm{K}^{+}$currents were recorded from EGFP-expressing cells as described in the legend to Figure 1. Records similar to those in $A$ and $B$ were obtained from all cells (Table 1); no cells lacking $I_{\text {Af }}$ were evident. Analysis of the decay phases of the currents provided the mean \pm SEM densities of $I_{\mathrm{Af}}$, $I_{\mathrm{As}}, I_{\mathrm{K}}$, and $I_{\mathrm{SS}}($ Table 1$)$, and mean \pm SEM $I_{\mathrm{Af}}$ densities were increased significantly in both Type I $(A)$ and Type II $(B)$ SCG cells as compared with wild-type Type I and II cells (Table 1 ).

of 31) of the SCG cells expressing Kv4.2W362F (Table 1). The density of this fast transient current is somewhat lower than $I_{\mathrm{Af}}$ density in wild-type Type I or II cells (Table 1), which could reflect incomplete removal of Kv4-induced currents. Alternatively, it is possible that there are two populations of $I_{\mathrm{Af}}$ channels, one generated by $\mathrm{Kv} 4 \alpha$-subunits and the other by another Kv subfamily. Analysis of the decay phases of the currents revealed that $\tau_{\text {decay }}$ values for $I_{\mathrm{Af}}$ in wild-type Type I and II cells are quite variable, ranging from 53 to $209 \mathrm{msec}$, and that there appear to be two populations of cells (Fig. 5). In cells expressing Kv4.2W362F, in contrast, the $\tau_{\text {decay }}$ for the rapid component of current decay ranged from 139 to $254 \mathrm{msec}$; there were no cells with $\tau_{\text {decay }}$ values in the 50-130 msec range (Fig. 5). In Kv4.2-expressing SCG cells, the $\tau_{\text {decay }}$ values for $I_{\mathrm{Af}}$ are all $<130 \mathrm{msec}$ (Fig. 5). Because the mean $\pm \mathrm{SEM}$ $\tau_{\text {decay }}$ values for $I_{\text {Af }}$ recorded from Kv4.2- and Kv4.2W362F- expressing cells are significantly different $(p<0.001)$ and the distribution of $\tau$ values is nonoverlapping (Fig. 5), it seems reasonable to suggest that there are two distinct types of $I_{\text {Af }}$ channels in SCG neurons that reflect the functional expression of distinct gene products. Interestingly, the identification of two molecularly distinct components of a "single" electrophysiologically defined current has been reported previously for $I_{\mathrm{Kr}}$ in Xenopus spinal neurons (Ribera, 1996) and for $I_{K}$, slow in mouse ventricular myocytes (Xu et al., 1999b). Recent studies have also revealed two components of recovery of $I_{\mathrm{Af}}$ from steady-state inactivation with time constants of $\sim 100$ and $\sim 1000 \mathrm{msec}(n=2)$, observations consistent with the suggestion that there are two components $I_{\mathrm{Af}}$. The more rapidly inactivating currents (mean $\tau_{\text {decay }} \sim 80 \mathrm{msec}$ ) present in the majority $(80 \%)$ of (Type I and II) SCG neurons reflect the expression of Kv4 $\alpha$-subunits. Although the molecular identity of the fast transient current $I_{\text {Af }}$ remaining in $(\sim 20 \%) \mathrm{Kv} 4.2 \mathrm{~W} 362 \mathrm{~F}$-expressing cells has not been defined, one potential candidate is $\mathrm{Kv} 1.4$, a Kv $\alpha$-subunit that also produces A-type $\mathrm{K}^{+}$currents when expressed in heterologous systems (Rudy, 1988). Importantly, Kv1.4 mRNA expression has been documented in SCG neurons (Dixon and McKinnon, 1996). Further experiments aimed at testing directly the hypothesis that Kv1.4 underlies the more slowly inactivating component of $I_{\text {Af }}$ are clearly warranted.

\section{$I_{\text {Af }}$ density and neuronal excitability}

Whole-cell current-clamp recordings from SCG neurons revealed distinct repetitive firing patterns, and cells were classified as phasic, adapting, or tonic based on stereotyped differences in the response to prolonged current injections (Fig. 6). The waveforms of individual action potentials recorded in phasic, tonic, and adapting cells are similar (Fig. 6), although action potential durations are briefer in tonic than in phasic or adapting cells (Table 2). There are also significant differences in the input resistances and current thresholds for action potential generation in adapting compared with phasic or tonic cells (Table 2). In SCG cells expressing Kv4.2W362F, the mean \pm SEM input resistances were increased compared with wild-type cells (Table 3). This finding suggests that (some) $I_{\mathrm{Af}}$ channels are open at rest, an observation supported by voltage-clamp data documenting an $I_{\mathrm{Af}}$ "window current" in the -70 to $-50 \mathrm{mV}$ range (Belluzzi et al., 1985a). Preliminary experiments have revealed that perfusion of wild-type SCG neurons with $300 \mathrm{~nm}$ Heteropoda toxin-3 (HрTx), a spider toxin (Sanguinetti et al., 1997) that blocks $I_{\text {Af }}$ selectively $(n=2)$, increases the input resistances of SCG neurons to a mean \pm SEM of $0.74 \pm 0.27 \mathrm{G} \Omega(n=17)$ from the control values of $0.45 \pm 0.11 \mathrm{G} \Omega(n=16)$. Importantly, neither the expression of $\mathrm{Kv} 4.2 \mathrm{~W} 362 \mathrm{~F}$ nor the application of HpT x-3 affects $I_{\mathrm{K} 1}$ density. Thus, the removal of $I_{\mathrm{Af}}$ specifically increases input resistance. The concomitant decrease in the current threshold for action potential generation (compare Table 2 and Table 3 ) reveals that $I_{\text {Af }}$ regulates excitability in SCG neurons by opposing depolarizing inputs and influencing the current required to reach threshold.

The results presented here also reveal that elimination of $I_{\mathrm{Af}}$ (by Kv4.2W362F expression) does not measurably affect action potential duration in SCG neurons. This finding seems in conflict with several previous studies suggesting that $I_{\mathrm{Af}}\left(I_{\mathrm{A}}\right)$ plays a role in action potential repolarization in SCG cells. Action potential durations, for example, reportedly decrease during late embryonic development in parallel with an increase in $I_{\text {Af }}$ density (Nerbonne 
and Gurney, 1989). In addition, in SCG neurons, action potential durations follow the steady-state inactivation curve for $I_{\mathrm{Af}}$ and are prolonged by 4-AP (Belluzzi et al., 1985a). These seemingly disparate findings could reflect the fact that additional currents (to $I_{\mathrm{A}}$ ) are changing during development and/or are affected by 4-AP. The molecular genetic approach to manipulating functional $\mathrm{K}^{+}$channel expression used here, however, should not be confounded by these uncertainties. Importantly, action potential durations are decreased when Kv4.2 is overexpressed and $I_{\mathrm{Af}}$ is increased.

\section{The role of $\boldsymbol{I}_{\mathrm{Af}}$ in determination of firing patterns}

The experiments completed here reveal that $I_{\mathrm{Af}}$ does play a prominent role in determining the repetitive firing properties of SCG neurons. Elimination of $I_{\mathrm{Af}}$ resulted in an increase in the input resistances of phasic and tonic (but not adapting) cells (Table 3 ). The loss of $I_{\mathrm{Af}}$ also resulted in an increased number (and percentage) of adapting cells (Table 3), whereas increasing the density of $I_{\text {Af }}$ decreased the number of adapting cells (Table 4). Taken together, these results suggest that low $I_{\mathrm{Af}}$ density is correlated with the adapting firing pattern. The changes in the distributions of cells also suggest that reductions in $I_{\text {Af }}$ density can convert phasic cells to the adapting phenotype. Adapting cells, in contrast, can be made to fire tonically when $I_{\mathrm{Af}}$ density is increased. Thus, although $I_{\mathrm{Af}}$ is not the sole determinant of repetitive firing patterns in SCG neurons, this conductance does play a prominent role.

Tonic cells are characterized by briefer action potentials than phasic or adapting cells (Table 2), and shortening action potential duration by increasing $I_{\mathrm{Af}}$ expression increases the percentage of tonic cells (Table 4). Nevertheless, $\sim 30 \%$ of Kv4.2-expressing cells are phasic (Table 4), suggesting that currents other than $I_{\text {Af }}$ play an important role in defining this firing class. One likely candidate is the M-current, $I_{\mathrm{M}}$, which has been linked previously to phasic firing in SCG and other neurons (Brown and Adams, 1980; Freshi, 1983; Galvan and Sedlmeir, 1984; Cassell et al., 1986; Wang and McKinnon, 1995). Blockade of the M-current has previously been shown to be sufficient to convert phasic SCG neurons to tonic firing (Cassell et al., 1986). Interestingly, the results here show that the same conversion may be accomplished with a decrease in action potential duration, which suggests that action potential duration is a key component of $I_{\mathrm{M}}$ activation and regulation of repetitive firing properties in SCG neurons. Further experiments aimed at testing this hypothesis directly are clearly warranted.

\section{REFERENCES}

Baro DJ, Levini RM, Kim MT, Willms AR, Lanning CC, Rodriguez HE, Harris-Warrick RM (1997) Quantitative single-cell-reverse transcriptionPCR demonstrates that A-current magnitude varies as a linear function of shal gene expression in identified stomatogastric neurons. J Neurosci 17:6597-6610.

Barry DM, Trimmer JS, Merlie JP, Nerbonne JM (1995) Differential expression of voltage-gated $\mathrm{K}^{+}$channel subunits in adult rat heart. Relation to functional $\mathrm{K}^{+}$channels? Circ Res 77:361-369.

Barry DM, Xu H, Schuessler RB, Nerbonne JM (1998) Functional knockout of the transient outward current, long-QT syndrome, and cardiac remodeling in mice expressing a dominant-negative Kv $4 \alpha$-subunit. Circ Res 83:560-567.

Belluzzi O, Sacchi O, Wanke E (1985a) Identification of delayed potassium and calcium currents in the rat sympathetic neurone under voltage clamp. J Physiol (Lond) 358:109-129.

Belluzzi O, Sacchi O, Wanke E (1985b) A fast transient outward current in the rat sympathetic neurone studied under voltage-clamp conditions. J Physiol (Lond) 358:91-109.

Brahmajothi MV, Campbell DL, Rasmusson RL, Morales MJ, Trimmer JS, Nerbonne JM, Strauss HC (1999) Distinct transient outward potassium current $\left(\mathrm{I}_{\text {to }}\right)$ phenotypes and distribution of fast-inactivating potassium channel alpha subunits in ferret left ventricular myocytes. J Gen Physiol 113:581-600.

Brown DA, Adams PR (1980) Muscarinic suppression of a novel voltagesensitive $\mathrm{K}^{+}$current in a vertebrate neurone. Nature 283:673-676.
Cassell JF, Clark AL, McLachlan EM (1986) Characteristics of phasic and tonic sympathetic ganglion cells of the guinea-pig. J Physiol (Lond) 372:457-483.

Chang JY, Martin DP, Johnson EM Jr (1990) Interferon suppresses sympathetic neuronal cell death caused by nerve growth factor deprivation. J Neurochem 55:436-445.

Coetzee WA, Amarillo Y, Chiu J, Chow A, Lau D, McCormack T, Moreno H, Nadal MS, Ozaita A, Pountney D, Saganich M, Vega-Saenz de Meira E, Rudy B (1999) Molecular diversity of $\mathrm{K}^{+}$channels. Ann NY Aca Sci 868:233-285.

Dixon JE, McKinnon D (1996) Potassium channel mRNA expression in prevertebral and paravertebral sympathetic neurons. Eur J Neurosci 8:183-191.

Fiset C, Clark RB, Larsen T, Giles WR (1997) A rapidly activating sustained current modulates repolarization and excitation-contraction coupling in adult mouse ventricle. J Physiol (Lond) 504:557-563.

Freshi JE (1983) Membrane currents of cultured rat sympathetic neurons under voltage clamp. J Neurophysiol 50:1460-1478.

Galvan M, Sedlmeir C (1984) Outward currents in voltage-clamped rat sympathetic neurones. J Physiol (Lond) 356:115-133.

Johns DC, Nuss HB, Marban E (1997) Suppression of neuronal and cardiac transient outward currents by viral gene transfer of dominantnegative Kv4.2 constructs. J Biol Chem 272:31598-31603.

Martina M, Schultz JH, Ehmke H, Monyer H, Jonas P (1998) Functional and molecular differences between voltage-gated $\mathrm{K}^{+}$channels of fastspiking interneurons and pyramidal neurons of the hippocampus. J Neurosci 18:8111-8125.

McFarlane S, Cooper E (1992) Postnatal development of voltage-gated $\mathrm{K}^{+}$currents on rat sympathetic neurons. J Neurophysiol 67:1291-1300.

Nerbonne JM, Gurney AM (1989) Development of excitable properties in mammalian sympathetic neurons. J Neurosci 9:3272-3286.

Nerbonne JM, Gurney AM, Rayburn H (1986) Development of the fast, transient outward $\mathrm{K}^{+}$current in embryonic sympathetic neurones. Brain Res 378:197-202.

Pankevych H, Kristufek D, Huck S (1999) Perinatal and postnatal regulation of Shaker-related genes in rat superior cervical ganglion. Soc Neurosci Abstr 29:789.

Pond AL, Scheve BK, Benedict AB, Petrecca K, Van Wagoner DR, Schrier A, Nerbonne JM (2000) Expression of distinct ERG proteins in rat, mouse and human heart. J Biol Chem 275:5997-6006.

Pongs O (1999) Voltage-gated potassium channels: from hyperexcitability to excitement. FEBS Lett 452:31-35.

Raff MC, Fields KL, Hakomori S-I, Mirsky R, Pruss RM, Winter J (1979) Cell-type-specific markers for distinguishing and studying neurons and the major classes of glial cells in culture. Brain Res 174:283-308.

Ribera AB (1996) Homogeneous development of electrical excitability via heterogeneous ion channel expression. J Neurosci 16:1123-1130.

Rudy B (1988) Diversity and ubiquity of K channels. Neuroscience 24:729-749.

Sanguinetti MC, Johnson JH, Hammerland LG, Kelbaugh PR, Volkmann RA, Saccomano NA, Mueller AL (1997) Heteropodatoxins: peptides isolated from spider venom that block Kv4.2 potassium channels. Mol Pharmacol 51:491-498.

Serodio P, Kentros C, Rudy B (1994) Identification of molecular components of A-type channels activating at subthreshold potentials. J Neurophysiol 72:1516-1529.

Song W-J, Tkatch T, Baranauskas G, Ichinohe N, Kitai ST, Surmeier DJ (1998) Somatodendritic depolarization-activated potassium currents in rat neostriatal cholinergic interneurons are predominantly of the A type and attributable to coexpression of Kv4.2 and Kv4.1 subunits. J Neurosci 18:3124-3137.

Storm JF (1990) Potassium currents in hippocampal pyramidal cells. Prog Brain Res 83:161-187.

Tkatch T, Baranauskas G, Surmeier DJ (2000) Kv4.2 mRNA abundance and A-type $\mathrm{K}^{+}$current amplitude are linearly related in basal ganglia and basal forebrain neurons. J Neurosci 20:579-588.

Wang H-S, McKinnon D (1995) Potassium currents in rat prevertebral and paravertebral sympathetic neurones: control of firing properties. J Physiol (Lond) 485:319-335.

Xu H, Li H, Nerbonne JM (1999a) Elimination of the transient outward current and action potential prolongation in mouse atrial myocytes expressing a dominant negative Kv4 $\alpha$-subunit. J Physiol (Lond) 519:11-21. Xu H, Barry DM, Li H, Brunet S, Guo W, Nerbonne JM (1999b) Attenuation of the slow component of delayed rectification, action potential prolongation, and triggered activity in mice expressing a dominantnegative Kv2 $\alpha$-subunit. Circ Res 85:623-633. 